\title{
A Covid Competition Dilemma: Legal and Ethical Challenges Regarding the Covid-19 Vaccine Policies during and after the Crisis
}

\author{
Mina Hosseini* \\ * Assistant Professor, University of Science and Culture, Tehran, Iran, e-mail: mina.hosseini@usc.ac.ir
}

\begin{abstract}
The Covid-19 pandemic has impacted multiple facets of our lives and created a number of legal and ethical dilemmas. One of the greatest challenges at present is the production and distribution of the Covid-19 vaccine. Refusing to supply Covid vaccines widely could affect millions worldwide, and the pandemic may last for a long time. The competition authorities' monitoring of the health sector in many countries has been subject to changes in the current crisis. The question is whether we can force the Covid-19 vaccine manufacturers, legally and ethically, to sell their products and share their information with their competitors. Furthermore, what are the post-pandemic consequences of policies adopted during the pandemic? This paper employs a descriptive-analytical method to examine the importance of competition and intellectual property policies as they relate to Covid-19. It concludes that instead of focusing on individual rights in a crisis, public rights need to be emphasised. However, we should not underestimate the post-pandemic consequences of policies adopted during the Covid-19 pandemic.
\end{abstract}

Keywords: Covid-19, competition law, vaccine policy, ethics, intellectual property

\section{Introduction}

The pharmaceutical industry is of vital importance due to its direct relationship with individuals and public health. Competition rules, intellectual property rights, price mechanisms, consumer protection and patient's health, are all factors which intersect in the pharmaceutical market. Some practices in the healthcare industry, such as anti-competitive agreements and firms' abuse of their dominant position, can increase prices, lead to a shortage of drugs, infringe consumer rights, endanger the health of consumers and put public health at risk (Cseres, 2005, pp. 207-210). In the pharmaceutical market, implementing competition rules aims to increase access to affordable drugs while also encouraging innovation. Regulating the pharmaceutical sector heavily depends on intellectual property rights and innovations originating from research and development. 
As such, controlling the market and interfering with policies must be conducted with great caution.

The vaccine market has proven to be one of the most profitable markets in the pharmaceutical industry, with an upward trend (Pitruzzella \& Arnaudo, 2017, p. 350). After the start of the Covid-19 pandemic, research and development budgets have significantly expanded globally to tackle the virus and prevent it by using vaccines. Global vaccine market revenue in 2020 was 59.2 billion US dollars (Statista, 2021a), and the forecast for 2021 is much higher. The vaccine industry before Covid-19 was a stable oligopoly globally, with the top four players - GlaxoSmithKline, Merck \& Co., Sanofi Pasteur and Pfizer - controlling 80 per cent of the total market share (Pitruzzella $\&$ Arnaudo, 2017, p. 352). According to recent statistics, up to this point (August 2021), ' $32.4 \%$ of the world population has received at least one dose of a COVID-19 vaccine, and $24.4 \%$ is fully vaccinated. 4.93 billion doses have been administered globally, and 34.25 million are now administered each day. Only $1.4 \%$ of people in low-income countries have received at least one dose' (Mathieu et al., 2021).

There are serious concerns regarding the distribution and allocation of the Covid-19 vaccine, and this is not a new problem; in another global pandemic (Influenza A) that broke out in 2009, several wealthy and developed countries bought all the stocks of vaccines, and the shortage of vaccines for developing countries became a severe issue (Bollyky et al., 2020, pp. 2462-2463). During the Covid-19 pandemic, the competition authorities' monitoring of the health sector in many countries underwent significant changes. Along with other active undertakings in the health sector, vaccine manufacturers were encouraged to collaborate because of the necessity of these efforts for citizens' welfare.

The problem of the vaccine manufacturer's intellectual property rights is a critical issue. Due to the principle of freedom of contract, the supplier's choice of whether to deal with specific individuals should not be prohibited or limited by the legislator. Still, in exceptional circumstances, such as when one firm is dominant, the refusal to supply can jeopardise the market competition. In a pandemic situation, pharmaceutical companies' exclusive intellectual property rights and the right to health may come into conflict. There has been a great deal of ethical debate regarding waiving intellectual property rights, compulsory licensing and the conflict between public and private rights.

This paper is divided into two parts. The first part deals with the competition authorities' reactions to the Covid-19 pandemic in the pharmaceutical sector (especially their vaccine policies), and the second part is dedicated to Covid-related intellectual property policies and discusses the challenges facing policy-makers from a legal and ethical point of view.

\section{Covid-19, competition law and vaccines policies}

Since the beginning of the Covid-19 crisis in the pharmaceutical sector, the competition authorities have had to make various decisions. Many competition authorities around the globe changed their competition policies to combat this unexpected outbreak. Some 
countries designed a specific framework for emergency competition law; for example, the European Commission released a 'Temporary Framework Communication' (European Commission, 2020a) on 8 April 2020 to regulate companies' collaboration regarding the Covid-19 outbreak. This communication was primarily aimed at facilitating cooperation to address shortages of essential hospital medicine supplies. According to the European Union (EU) Covid-19 policy, suppliers of critical and scarce goods are permitted to cooperate in production and distribution. Even some behaviours which are usually in direct violation of EU competition law regulations can be regarded as appropriate and even beneficial in the Covid era. Outside the scope of this declaration and the essential circumstances of the pandemic, such arrangements are not approved by the EU competition authorities (Costa-Cabral et al., 2021, p. 21). The publication of comfort letters was also of importance in this regard. The European Commission provided a comfort letter to Medicines for Europe (European Commission DGC, 2020), that suggests voluntary cooperation in the pharmaceutical sector to decrease the risk of the shortage of medicines to treat Covid-19 patients.

A popular competition policy involved granting licenses to economic enterprises in the pharmaceutical sector to exchange information and enter into agreements with competitors; European competition authorities encouraged cooperation between competitors in vaccines production as part of its Covid competition policies. In March 2020, the UK Competition and Markets Authority (CMA) published an 'Open letter to the pharmaceutical and food and drink industries'. In this, CMA responded to some behaviours (including charging unjustifiably high prices for essential goods or making misleading claims about efficacy [Competition and Markets Authority, 2020]). On 25 March 2020, the CMA indicated in a guidance note entitled 'CMA approach to business cooperation in response to Covid-19' that it facilitates collaboration between competitors, but only when that cooperation is to discuss problems resulting from the Covid-19 crisis. It would not go further or last longer than is essential (Competition and Markets Authority, 2021).

Another competition policy in the pandemic situation involved collaboration between competition authorities and section regulators to control and monitor some agreements between competitors. For example, in Iceland, sector regulators have played an essential role in designing emergency competition policies. These regulators in particular sectors (such as the Icelandic Directorate of Health and the Icelandic Medicines Agency in the pharma sector) have access to the cooperation between undertakings during the Covid-19 period. The Icelandic competition authority handles the requests for exemption on time-sensitive problems related to Covid-19 within 48 hours after their receipt. Some examples of these exemptions are given on the Authority's website. For instance, cooperation between pharmaceutical importers and distributors ensures access to critical pharmaceuticals (Decision No. 11/2020; Icelandic Competition Authority, 2020).

Prompt and decisive confrontation with some anti-competitive practices that were to the detriment of consumers (such as excessive pricing in the pharmaceutical sector and collusion between competitors to divide the market or raise prices) has also proved to be an effective policy. For example, the Spanish competition watchdog (CNMC) 
declared that it had launched inquiries into various sectors after several anti-competitive behaviours were discovered in the health sector. CNMC emphasised that the authority is actively tracking pricing and supply shortages in the health products industry (in connection with products such as sanitising gels and the raw materials used in their production) to detect anti-competitive activities leading to possible price changes (Rakić, 2020, p. 31).

In the same vein, the Greek competition regulator started to monitor prices of goods on the health market during the crisis. It sent information requests to numerous companies engaged in the production, distribution, and marketing chains of health-related goods (Costa-Cabral et al., 2021, pp. 16-17). The requested information was mainly connected with reports of and complaints about price rises and output limits (Hellenic Competition Commission, 2020). A team of economists reviewed the results. The Greek competition authority also conducted inquiries into businesses that did not respond to its request. Vaccine policies were among the competition policies of competition authorities. The World Health Organisation (WHO) reports that several different vaccines (from different producers) such as the AstraZeneca, Janssen, Pfizer-BioNTech, Moderna and Sputnik V vaccines have been provided up to this time (World Health Organization, 2021a).

According to EU officials, the EU vaccines strategy is based on meeting objectives such as: 'Ensuring the quality, safety and efficacy of vaccines, securing swift access to vaccines for the member states and their populations while leading the global solidarity effort and ensuring equitable access to an affordable vaccine as early as possible' (European Commission, 2021b). The European competition authorities have also been encouraging cooperation between competitors in vaccines production. The Matchmaking Experience was an online event hosted on b2match, a third-party website run by Sociedade Portuguesa de Inovaçao, on 29 and 31 March 2021. Several meetings between potential alliances and participating companies were scheduled to exchange information and Covid-19 vaccine-related data. The European Commission issued a comfort letter on 21 March 2021 (European Commission, 2021a), stating that in the light of competition law considerations, the collaboration between participating companies in the Matchmaking Event, particularly the sharing of related commercial details, does not pose questions under Article 101 of the Treaty on the Functioning of the European Union, as long as the competition law principles are followed. In parallel to the EU, each Member State has taken measures to promote competition in the Covid-19 vaccine market.

The European Union's policies during the Covid-19 crisis encouraged state aid, especially in connection with health-related products. European Commission guidance (on 8 April 2020) and the EU Communication from the Commission on an Amendment to the Temporary Framework for State aid measures to support the economy in the current Covid-19 outbreak, of 3 April 2020, states that the manufacturing of essential drugs, in particular, should be improved where possible or kept at current levels. Member states were advised to encourage companies to expand their manufacturing capability, primarily through tax incentives and state aid. 
State aid policies have been subject to change in the Covid period. Within the EU Commission's Temporary Framework, there are several instances of state aid. Germany, for example, created an umbrella scheme to fund some aspects of Covid-19-related research and development, as well as investments in testing and upscaling the infrastructures that contribute to the development of Covid-19-relevant pharmaceuticals and facilities (European Commission, 2020b). The Italian state aid vaccine development project by ReiThera, an Italian 40 million euro measure that aims to support the development of a new coronavirus vaccine, ${ }^{1}$ is another example of Covid-19 state aid cases. The European Commission Directorate General for Competition has also established a dedicated mailbox and phone number to assist the Member States with any questions or requests to discuss the Temporary Framework. The Directorate General for Competition has released a number of templates to assist Member States in creating their national strategies under the Recovery and Resilience Facility (European Commission, 2021c). ${ }^{2}$

One of the successful competition cases regarding this issue was the investigation into Roche Diagnostics. The competition authority of the Netherlands announced on 3 April 2020 that it would take no further steps in the inquiry into Roche Diagnostics. The problem had been the refusal of this firm to comply with the expansion of capability for Covid-19 testing. Roche and the competition authority came to an agreement whereby Roche committed to sharing technology with its competitors to scale up production (Authority for Consumers and Markets, 2021). The necessity of these actions and the supremacy of public health over individual benefit is apparent in this case and can be used as an example of sharing vaccine information and data to overcome the crisis. Overall, the most effective way to enforce competition law rules in the pandemic era is by combining the above solutions.

\section{Intellectual property Covid policies: A legal and ethical challenge}

As mentioned in the UN Sustainable Development Goal (The United Nations, 2015): Up to 2030, 'to achieve universal health coverage, including financial risk protection, access to quality essential healthcare services and access to safe, effective, quality and affordable essential medicines and vaccines for all' is an important goal for the UN. As the WHO Director-General stated in January 2021, 'the world is on the brink of a catastrophic moral failure - and the price of this failure will be paid with lives and livelihoods in the world's poorest countries' (World Health Organization, 2021b). The right to receive therapeutic and life-saving interventions is one of every patient's most basic rights in pandemic situations. The right to health as one of the fundamental human rights is declared in numerous international human rights documents (Tobin, 2012),

SA.61774 COVID-19, State Aid SA.61774 (2021/N) - Italy COVID-19: Vaccine development project by ReiThera S.r.l., Brussels, 26.2.2021 C (2021) 1458 final.

2 See also Regulation (EU) 2021/241 of the European Parliament and of the Council of 12 February 2021 establishing the Recovery and Resilience Facility. 
such as Article 55(a) of the UN Charter, the Constitution of the World Health Organization, the International Covenant on Economic, Social and Cultural Rights, the Convention on the Elimination of All Forms of Racial Discrimination (1965) and the Convention on the Elimination of All Forms of Discrimination against Women (1979). According to Article 12 of the International Covenant on Economic, Social and Cultural Rights, governments must provide adequate and prompt treatment to protect citizens' right to health (Ssenyonjo, 2011, pp. 969-971).

There has been much debate regarding waiving intellectual property rights, compulsory licensing, and the conflict between public and private rights. Intellectual property waivers request that countries be excluded from the requirements of the Agreement on Trade-Related Aspects of Intellectual Property Rights (Love, 2021). In compulsory licensing, the government allows a third party to use the patented vaccine. The question concerns the possibility of violating the rights of a particular group of people under the pretext of protecting society. This challenge is severe in a pandemic. Article 31 of TRIPS requires governments, in certain circumstances, to allow domestic producers to produce a patented product without the patent holder's consent. In addition, Article 31 will enable countries to impose compulsory licenses in a 'social emergency or other extraordinary situations' or in the case of 'public non-commercial use' (World Health Organization, 2002).

In October 2020, India and South Africa requested World Trade Organization (WTO) representatives to waive patent, copyright, industrial design and undisclosed information (trade secrets) in the context of the 'prevention, containment, or care of COVID-19'. Furthermore, they asked for this waiver to continue until universal vaccination is in effect worldwide and the majority of the world's population has achieved immunity (Council for Trade-Related Aspects of Intellectual Property Rights, 2020). This issue had a mixed reception among scholars and governments, with many arguing both in support of and against such special dispensation.

\subsection{Opponents' arguments}

The United States (at first), the EU, Switzerland, Germany, the United Kingdom and Japan were all against the TRIPS waiver. However, on 5 May 2021, the U.S. Government announced that it 'supports the waiver of those protections for COVID-19 vaccines' (Office of the United States Trade Representative, 2021), although this support only covers vaccines, leaving other products like diagnostics, treatments, ventilators, respirators, syringes and refrigerators that keep doses cold during preparation and transport unprotected (Bonadio \& Fontanelli, 2021). Some of the essential arguments of opponents of waiving intellectual property and compulsory licensing are as follows: The right to own private property, freedom of contract and the protection of the inventor's intellectual rights are legally protected rights. Moreover, intellectual property waiving and compulsory licensing are morally wrong because they are considered a kind of theft. Furthermore, waiver and compulsory licenses destroy the pharmaceutical companies' 
ability to innovate and incentives to produce and distribute new drugs and vaccines (Bagley, 2017, pp. 2468-2470; Sangameshwaran, 2021).

Some scholars argue that intellectual property waiving of Covid-19 vaccines is futile and symbolic. They believe that even if the developing countries can remove intellectual property barriers and obtain permits to manufacture vaccines, they lack the know-how expertise, infrastructure and qualified staff to produce these pharmaceutical products. Furthermore, current TRIPS flexibilities have done little to help (Huizen, 2021). In its opposition to TRIPS waiver, the U.K. Government, in a statement on July 2021 in WTO, asserted that '[i]t was the intellectual property regime that has enabled the extraordinary scientific advances of the last year, including the development of safe and effective vaccine'.

Germany, as one of the most vigorous opponents of TRIPS waiver, argues that 'the protection of the intellectual property is a source of innovation and must remain so in the future' (DW, 2021). Germany was the WHO's most significant donor during Covid-19, contributing 881.6 million dollars. It is also a substantial contributor to the COVAX, having donated over 2.58 billion dollars to date (Sangameshwaran, 2021).

The statement of International Federation of Pharmaceutical Manufacturers and Associations on 'WTO TRIPS intellectual property waiver' published on 5 May 2021 called the U.S. Government solution 'the wrong answer to what is a complex problem. The Federation emphasises that 'waiving patents of COVID-19 vaccines will not increase production nor provide practical solutions needed to battle this global health crisis' (International Federation of Pharmaceutical Manufacturers \& Associations, 2021). Albert Bourla, Chairman and Chief Executive Officer of Pfizer, at an open day on 10 May 2021, emphasised that 'equity does not mean we give everyone the same. Equity means we give more to those that need more' and in opposition to the TRIPS wavier he argued that 'entities with little or no experience in manufacturing vaccines are likely to chase the very raw materials we require to scale our production, putting the safety and security of all at risk' (Bourla, 2021).

\subsection{Proponents' arguments}

A popular opinion also argues that global public health depends on the free availability of these products (Bagley, 2017, pp. 2492-2493). According to the freedom of contract principle, the supplier's will to enter into a contract with certain individuals, and refuse to supply others is not illegal, nor can be prohibited by the legislator (Williston, 1920; Cserne, 2012). Nevertheless, when a firm is in a dominant position, such a refusal to supply can put the market competition in danger, and must be managed by competition law rules. Refusal to supply by non-dominant firms is not prohibited in EU competition law, although it may harm some markets. In Case T-41/96 Bayer $v$ Commission of the European Communities such an issue was addressed by the European Court of Justice.

Some believe that the arrangements for technology transfer and production sharing have already been established (such as those between BioNTech and Pfizer, Oxfarm/ AstraZeneca and Novavax with the Serum Institute). The existence of these 
arrangements proves that the claims that technology transfer is too complicated or takes too long are exaggerated (Love, 2021). Furthermore, as there may be only one solution, if developing countries seek to acquire the scientific and technical knowledge necessary for vaccine production without using the existing expertise of vaccine intellectual property holders and scientists, the results might be a great disappointment. This may prolong the pandemic indefinitely and lead to an irrational waste of resources.

The violation of individual rights to social protection is similar to violating personality rights in order to protect community rights. As every person has the right to physical integrity, any physical assault on a person is prohibited and entails the assailant's criminal and civil liability. However, there are exceptions to such protection, and waiving the intellectual property rights is one of them. During the Covid-19 pandemic, the breach of individual rights can be sanctioned to protect the right to public health (McMahon, 2021, pp. 142-148). Although some frameworks, including COVAX, are designed to distribute vaccines in low-income and middle-income nations in the current pandemic, it seems that these arrangements are insufficient, and more solutions are required to end this health crisis (Roope et al., 2020, pp. 558-560; Vercler, 2020, pp. 1-3; Catania, 2021, pp. 455-459).

It appears that ensuring collective benefits, even if it harms certain individuals, is morally justifiable. Even in non-pandemic contexts, the theory of essential facilities ${ }^{3}$ and compulsory pharmaceutical licensing has justified the coercion of producers for the benefit of society (Son, 2019; Lo Bianco, 2020, pp. 2-4).

In an open letter published in July 2021, more than 120 academic lawyers and intellectual property experts from around the globe called on governments to support a TRIPS waiver to battle the Covid-19 pandemic. They claimed that ' $[t]$ he intellectual property system has failed in the past to create market incentives for vaccine development' and 'in the case of COVID-19 vaccines, such a market failure has been mitigated with unprecedented public funding and de-risking of research and development costs through advance market commitments by governments' (Kang et al., 2021, p. 2). Jecker and Atuire (2021) also supported the anti-waiver analyses from a utilitarian and deontological ethics point of view. The utilitarian analysis examines the idea that intellectual property protection is essential to keep motivation and innovation alive. The authors then asked how much money is enough to ensure the survival of this motivation and innovation, as well as could pharmaceutical companies and vaccine producers 'earn less and the incentive to innovate remain intact?' From the deontological point of view, 'no one can rightfully take what is theirs'. They argued that producing Covid-19 vaccines would be impossible without a massive amount of public investment (Jecker \& Atuire, 2021, p. 596).

A recent development in this regard occurred in Brazil. On 29 April 2021, the Brazilian Senate approved a bill facilitating the compulsory licensing of Covid-19 vaccine

\footnotetext{
In response to a written question in 2020, the European Commission stated that: 'In our competition enforcement, the "essential facility doctrine" may require a dominant firm to share its assets with others, if an asset is "essential" (indispensable) for others to compete effectively in the market and if refusing access would eliminate effective competition on that market and thus cause consumer harm.' www.europarl.europa.eu/doceo/ document/E-9-2020-000595_EN.html
} 
patents. The Senate passed the bill on 12 August 2021. The bill will now go to the Brazilian President for his signature. It modifies some aspects of Brazilian patent law addressing compulsory licensing and allows for the waiver of patent rights in times of international or national crisis and emergency (Eakin, 2021).

\section{Post-pandemic effects of Covid-19 policies}

An important question associated with the competition and IP policies relating to the Covid pandemic relates to the post-Covid situation. It is essential to consider this because there are so many concerns regarding the post-pandemic effects of pandemic policies. It remains unclear the degree to which the post-pandemic period will be different from the pre-pandemic era. At this stage of understanding, it seems that competition law enforcement during a crisis is vital, and cooperation among rivals can benefit consumers. However, we should not underestimate the post-crisis repercussions of competition crisis policies. Data sharing, competitor collaboration, vaccine intellectual property challenges, and anti-competitive behaviour by pharmaceutical companies are all critical concerns in the post-pandemic times.

Given the dominant position of vaccine producers, widespread horizontal cooperation, price gouging (Williams, 2020, pp. 183-184), interrupted supply chains (Yu et al., 2021) and excessive protectionism during the crisis (Jenny, 2020), it appears that postcrisis competition law and policy will differ from the pre-crisis era. Some pharmaceutical companies will regard themselves as 'pandemic champions', and post-crisis competition law enforcement may be difficult. One of the concerns regarding the TRIPS waivers in the long term centres on incentives for innovation and investment. Some believe that it would simply slow vaccine research and development and make it more challenging to prevent and combat subsequent pandemics. Opponents of a TRIPS waiver ask who has the motive to create next-generation vaccines if intellectual property rights are required to be waived?

On 9 November 2020, BioNTech, a German biotech firm, and Pfizer, a U.S. pharmaceutical company, were the first to declare that a validated Covid-19 vaccine would be available for mass manufacturing. For the last 10 to 20 years, several small creative start-ups such as BioNTech and Moderna have pioneered mRNA technology for cancer therapy, often without generating a profit. BioNTech reported an annual operational loss of about 82.4 million euros in 2020 compared to a 181.5 million euro loss in 2019. At the same time, BioNTech's annual operational losses were in the thousands of euros range from 2017 to 2020 (Statista, 2021b). These businesses will spend more extensively on innovative cancer treatments and infectious disease vaccinations, thanks to the profits gained from the Covid-19 vaccines. Corporations will think carefully before risking their investment in the event of a future health crisis because they know it may harm the firm in the long term. These concerns are well-founded, but it is important to remember that decreasing post-pandemic incentives cannot be more important than human lives. In low- and middle-income countries, the number of people dying because of Covid is much higher than in developed countries. In one 
world, many people are fully vaccinated and waiting for a booster dose. At the same time, many people, including influential scientists, physicians, health providers, artists and scholars, are dying without vaccines in another world.

In the pandemic and post-pandemic era, the pharmaceutical industry will continue to have a monopoly on vaccine expertise and technological platforms. Every company is indeed more concerned with profitable operations than with global health. Still, competition policy and intellectual property policies must monitor and manage the vaccine markets even in the post-pandemic times. The pharmaceutical companies gained a great deal during the pandemic, and the dominant positions of vaccine producers have led to price increases of the vaccines. In August 2021, the price of the Pfizer vaccine was raised by more than a quarter, and Moderna by more than a tenth in their latest contract with the EU (Financial Times, 2021). The dominant position of these companies can generate some concerns about competition and lead to anti-competitive practices.

Harm to consumers is another possible effect of competition and intellectual property policies. Data sharing, cooperation, collaboration and information exchange among competitors can lead to collusion, price increases and the endangering of consumer's health. Sharing information without technological platforms, technology transfer and training can also lead to low-quality products that harm consumers.

\section{Conclusion}

Competition authorities must formulate appropriate rules to manage the crisis effectively. These regulations should be regularly updated as the dimensions of the situation become apparent, and some efforts should be allocated to the post-crisis phase. Immediate investigation and prosecution of anti-competitive practices, while permitting some agreements and exchange of information, especially regarding medicines and vaccines during the health crisis, is necessary. Some anti-competitive practices, such as excessive pricing, collusion between pharmaceutical companies and refusal to deal have increased in the Covid-19 era. Some of the presently permitted data-sharing and collaborations between competitors may harm consumers in the post-Covid period, and the consequences are not yet clear.

Vaccines are an essential part of pandemic-related products, and some competition authorities up to this point have not had clear policies regarding vaccines. Where the lives of millions of people worldwide are in danger, these authorities must use various methods to encourage or even compel vaccine producers to collaborate with rivals and exchange the necessary data.

Creating a balance between the intellectual property rights of Covid-19 vaccine producers, the public right to health and the competition rules is thus the key to an effective competition policy to help overcome this global crisis.

In a situation where the lives of millions of people worldwide are in danger, the competition authorities, using various mechanisms, must force the companies that possess the vaccine technology to cooperate with competitors and share the data, technologies and information as required. Because the right to health and receiving 
appropriate treatment are among the fundamental human rights, the issues regarding waiving intellectual property rights and compulsory licensing of Covid-19 vaccines are legally and ethically justifiable.

\section{References}

Authority for Consumers and Markets (2021). ACM has Confidence in Commitments Made by Roche to Help Solve Problems with Test Materials. Online: www.acm.nl/en/publications/acm-has-confidencecommitments-made-roche-help-solve-problems-test-materials

Bagley, M. A. (2017). The Morality of Compulsory Licensing as an Access to Medicines Tool. Minnesota Law Review 102, 2463-2494.

Balsam, K. F., Martell, Ch. R., Jones, K. P. \&Safren, S. A. (2019). Affirmative Cognitive Behavior Therapy with Sexual and Gender Minority People. In G. Y. Iwamasa \& P. A. Hays (Eds.), Culturally Responsive Cognitive Behavior Therapy: Practice and Supervision (2nd ed., pp. 287-314). American Psychological Association. Online: https://doi.org/10.1037/0000119-012

Bollyky, T. J., Gostin, L. O. \& Hamburg, M. A. (2020). The Equitable Distribution of COVID-19 Therapeutics and Vaccines. Journal of the American Medical Association, 323(24), 2462-2463. Online: https://doi. org/10.1001/jama.2020.6641

Bonadio, E. \& Fontanelli, F. (2021). Push for COVID-19 Vaccine Patent Waiver isn't a Panacea: But it could Nudge Companies to Share. Online: https://theconversation.com/push-for-covid-19-vaccine-patentwaiver-isnt-a-panacea-but-it-could-nudge-companies-to-share-160802

Bourla, A. (2021). An Open Letter from Albert Bourla to Pfizer Employees. Online: www.pfizer.com/news/ hot-topics/why_pfizer_opposes_the_trips_intellectual_property_waiver_for_covid_19_vaccines

Brown, L. S. (2018). Feminist Therapy (2nd ed.). American Psychological Association. Online: https://doi. org/10.1037/0000092-000

Catania, L. J. (2021). SARS-CoV-2 and the COVID-19 Pandemic. Foundations of Artificial Intelligence in Healthcare and Bioscience. Online: https://doi.org/10.1016/B978-0-12-824477-7.00004-3

Competition and Markets Authority (2020). An Open Letter to the Pharmaceutical and Food and Drink Industries. Online: https://assets.publishing.service.gov.uk/government/uploads/system/uploads/ attachment_data/file/874240/COVID_19_Open_letter_to_pharmaceutical_and_food_and_drink_ industries2.pdf

Competition and Markets Authority (2021). CMA Approach to Business Cooperation in Response to COVID-19. Online: https://assets.publishing.service.gov.uk/government/uploads/system/uploads/ attachment_data/file/875468/Covid19_guidance_-.pdf

Costa-Cabral, F., Hancher, L., Monti, M. \& Ruiz Feases, A. (2021). EU Competition Law and COVID-19. TILEC Discussion Paper No. DP2020-007. Online: https://doi.org/10.2139/ssrn.3561438

Council for Trade-Related Aspects of Intellectual Property Rights (2020). Waiver from Certain Provisions of the TRIPS Agreement for the Prevention, Containment and Treatment of COVID-19: Communication from India and South Africa, World Trade Organization, IP/C/W. Online: https://docs.wto.org/dol2fe/ Pages $/$ SS/directdoc.aspx ?filename $=q: / I P / C / W 669 . p d f \& O p e n=$ True

Cseres, K. J. (2005). Competition Law and Consumer Protection. Kluwer Law International.

Cserne, P. (2012). Freedom of Contract and Paternalism: Prospects and Limits of an Economic Approach. Springer. Online: https://doi.org/10.1057/9781137000323

DW (2021). Germany Rejects US Push to Waive COVID Vaccine Patents. Online: www.dw.com/en/ germany-rejects-us-push-to-waive-covid-vaccine-patents/a-57453453

Eakin, B. (2021). Brazil Senate Passes COVID Vaccines License-Waiver Bill. Online: www.law360.com/ articles/1412275/brazil-s-senate-passes-covid-vaccines-license-waiver-bill?copied=1 
European Commission (2020a). Communication from the Commission Temporary Framework for assessing antitrust issues related to business cooperation in response to situations of urgency stemming from the current COVID-19 outbreak, Brussels, 8.4.2020 C(2020) 3200, final.

European Commission (2020b). The EU Commission Approves the German 'Umbrella' Scheme to Support Research, Development and Testing as well as Production of COVID-19 Relevant Products. Art. $\mathrm{N}^{\circ}$ 94568. Online: www.concurrences.com/en/bulletin/news-issues/april-2020/the-eu-commission-approvesgerman-umbrella-scheme-to-support-research

European Commission (2021a). Comfort Letter. Cooperation at a Matchmaking Event: Towards COVID19 vaccines upscale production, 25/03/2021.

European Commission (2021b). EU Vaccines Strategy. Online: https://ec.europa.eu/info/live-work-travel$\mathrm{eu} /$ coronavirus-response/public-health/eu-vaccines-strategy_en

European Commission (2021c). State aid Rules and Coronavirus. Online: https://ec.europa.eu/competition/ state_aid/what_is_new/covid_19.html

European Commission DGC (2020). Comfort Letter: Coordination in the Pharmaceutical Industry to Increase Production and to Improve Supply of Urgently Needed Critical Hospital Medicines to Treat COVID-19 Patients. Brussels, 08/04/2020 COMP/OG - D (2020/044003).

Financial Times (2021, August 1). Pfizer and Moderna raise EU Covid vaccine prices. Online: www.ft.com/ content/d415a01e-d065-44a9-bad4-f9235aa04cla

Hellenic Competition Commission (2020). The Interim Results of HCC's Investigations on Health and Hospital Equipment During Covid-19 Pandemic. Online: www.epant.gr/en/enimerosi/press-releases/ item/1083-press-release-the-interim

Huizen, J. A. (2021, April 9). Herd immunity may take 4.6 years due to vaccine nationalism. MedicalNewsToday. Online: www.medicalnewstoday.com/articles/herd-immunity-may-take-4-6-years-due-to-vaccinenationalism\#Continuing-the-inequity

Icelandic Competition Authority (2020, March 22). The Icelandic Competition Authority opens an information center as a response to the antitrust challenges posed by the current COVID-19 outbreak. e-Competitions March 2020, Art. N 93892. Online: www.concurrences.com/en/bulletin/news-issues/march-2020/ the-icelandic-competition-authority-opens-an-information-center-as-a-response

International Federation of Pharmaceutical Manufacturers \& Associations (2021). Statement on WTO TRIPS Intellectual Property Waiver. Online: www.ifpma.org/resource-centre/ifpma-statement-on-wtotrips-intellectual-property-waiver/

Jecker, N. S. \& Atuire, C. A. (2021). What's Yours is Ours: Waiving Intellectual Property Protections for COVID-19 Vaccines. Journal of Medical Ethics, 595-598. Online: https://doi.org/10.1136/medethics2021-107555

Jenny, F. (2020). Covid-19 and the future of competition law enforcement. Competition Law International 16(1).

Kang, H., McMahon, A., Dutfield, D., McDonagh, L. \& Thambisetty, S. (2021). Academic Open Letter in Support of the TRIPS Intellectual Property Waiver Proposal. LSE Law - Policy Briefing Paper, No. 46. Online: https://doi.org/10.2139/ssrn.3885568

Lo Bianco, F. (2020). Comparative Patent Compulsory Licensing under COVID-19. SSRN 3580407, 1-4. Online: https://doi.org/10.2139/ssrn.3580407

Love, J. (2021). Would Exempting COVID-19 Vaccines from Intellectual Property Rights Improve Global Access and Equity? Online: www.cgdev.org/debate/would-exempting-covid-19-vaccines-intellectualproperty-rights-improve-global-access

Mathieu, E., Ritchie, H., Ortiz-Ospina, E., Roser, M., Hasell, J., Appel, C., Giattino, Ch. \& Rodés-Guirao, L. (2021). A Global Database of COVID-19 Vaccinations. Nature Human Behaviour 5, 947-953. Online: https://doi.org/10.1038/s41562-021-01122-8

McCauley, S. M. \& Christiansen, M. H. (2019). Language Learning as Language Use: A Cross-Linguistic Model of Child Language Development. Psychological Review, 126(1), 1-51. Online: https://doi. org/10.1037/rev0000126 
McMahon, A. (2021). Global Equitable Access to Vaccines, Medicines and Diagnostics for COVID-19: The Role of Patents as Private Governance. Journal of Medical Ethics, 47(3), 142-148. Online: https://doi. org/10.1136/medethics-2020-106795

Office of the United States Trade Representative (2021). Statement from Ambassador Katherine Tai on the Covid-19 Trips Waiver. Online: https://ustr.gov/about-us/policy-offices/press-office/press-releases/2021/ may/statement-ambassador-katherine-tai-covid-19-trips-waiver

Pitruzzella, G. \& Arnaudo, L. (2017). On Vaccines, Pharmaceutical Markets, and a Role for Competition Law in Protecting (also) Human Rights. European Competition Law Review, 7(38), 347-352. Online: https://doi.org/10.2139/ssrn.3033879

Rakić, I. (2020). Competition Law in the Age of Covid-19. Anali Pravnog fakulteta u Beogradu, 20. DOI: https://doi.org/10.5937/AnaliPFB2002025R

Roope, L. S. et al. (2020). How should a Safe and Effective COVID-19 Vaccine be Allocated? Health Economists Need to be Ready to Take the Baton. PharmacoEconomics-open, 4(4), 557-561. Online: https://doi.org/10.1007/s41669-020-00228-5

Sangameshwaran, R. (2021). Understanding Germany's Trenchant Opposition to the TRIPS Waiver. Online: https://genevahealthfiles.substack.com/p/understanding-germanys-trenchant

Son, K. B. (2019). Importance of the Intellectual Property System in Attempting Compulsory Licensing of Pharmaceuticals: A Cross-Sectional Analysis. Globalization and Health, 15(1), 1-8. Online: https:// doi.org/10.1186/s12992-019-0485-7

Ssenyonjo, M. (2011). Reflections on State Obligations with Respect to Economic, Social and Cultural Rights in International Human Rights Law. The International Journal of Human Rights, 15(6), 969-1012. Online: https://doi.org/10.1080/13642981003719158

Statista (2021a). Global Vaccine Market Revenues from 2014 to 2020 in Billion US Dollars. Online: www. statista.com/statistics/265102/revenues-in-the-global-vaccine-market

Statista (2021b). Operating Loss of BioNTech SE from 2017 to 2020. Online: www.statista.com/ statistics/1186022/operating-loss-biontech-se/

The United Nations (2015). Transforming Our World: The 2030 Agenda for Sustainable Development.

Tobin, J. (2012). The Right to Health in International Law. Oxford University Press.

Vercler, C. (2020). Navigating the Ethical Scylla and Charybdis of the COVID Vaccine. Journal of Pediatric Rehabilitation Medicine, 13(3), 229-231. Online: https://doi.org/10.3233/PRM-200025

Williams, O. D. (2020). COVID-19 and Private Health: Market and Governance Failure. Development 63(2), 181-190. Online: https://doi.org/10.1057/s41301-020-00273-x

Williston, S. (1920). Freedom of Contract. Cornell Law Quarterly, 6(4), 365-380.

World Health Organization (2002). Implications of the Doha Declaration on the TRIPS Agreement and Public Health. Online: https://apps.who.int/iris/handle/10665/67345

World Health Organization (2021a). Coronavirus Disease Vaccines. Online: www.who.int/news-room/q-a-detail/ coronavirus-disease-(covid-19)-vaccines

World Health Organization (2021b). Director-General's Opening Remarks at 148th Session of the Executive Board. Online: www.who.int/director-general/speeches/detail/who-director-general-s-opening-remarksat-148th-session-of-the-executive-board

Yu, Z., Razzaq, A., Rehman, A., Shah, A., Jameel, K. \& Mor, R. S. (2021). Disruption in Global Supply Chain and Socio-Economic Shocks: A Lesson from COVID-19 for Sustainable Production and Consumption. Operations Management Research. pp. 1-16. Online: https://doi.org/10.1007/s12063-021-00179-y 